\title{
騒音下における管内定在波を用いた管長高精度計測について
}

\author{
田 中 正 吾* 中 山 正 行*
}

\author{
A High Accurate Pipe Length Measurement Under Noisy Environment \\ Using Stationary Waves in the Pipe \\ Shogo TANAKA* and Masayuki NAKAYAMA*
}

\begin{abstract}
The authors previously developed an accurate pipe length measurement system based on a dynamic system theory applied to the stationary waves in the pipe. In manufacturing fields, however, the system can not always be directly applied to the pipes with open ends, because extremely large noises outside the pipes invade into the pipes and cause successive phase shifts in the stationary waves.

The paper proposes a method which realizes an accurate pipe length measurement under such a noisy environment by selecting an optimal data window and also the optimal modes.
\end{abstract}

Key Words: pipe length measurement, stationary wave, noisy environment, linear dynamic system, maximum likelihood method

\section{1. 納 言}

計測の分野においては，水道・ガスなどの配管関係を始め とし，管の長さを間接計測することが重要な役割を果たす場 合がしばしば見うけられる。このような管長の間接計測法と してはパルスエコー法が良く知られている ${ }^{1), 2)}$.この方法は, 管の一端より送波した音波が他端で反射し，再び返ってくる までの往復音波伝播時間より管長を計測する方法であるが， 送受波器（スピーカやマイクロホン）がダイナミクスを持つ ため，反射波は紡錘型振動波形となり，そのため，反射波の 正確な立ち上がり時刻を求めることは雑音環境下では困難で ある。これに加え，音波の入力装置が必要であるため，高コ ストとなる。一方，パルスエコー法と異なる方式として，管 内に定在波を発生させ，管長と定在波周波数の一対一関係よ り管長を計測する方法も報告されているが3),4)，いずれも音 波の入力装置が必要である.

このような観点から，著者らはこれまで，管に衝撃を与え たりして管内に発生する定在波を利用した管長高精度計測法 を提案した ${ }^{5) 〜 7)}$. 具体的には, 管内に生じる定在波のいくつ かのモードの音圧変動およびその時間微分を線形ダイナミッ クシステムの状態変数として採用し，このダイナミックシス テムに管長および観測雑音分散を未知パラメータとしたカル マンフィルタおよび最尤法を適用することにより，管長をオ ンライン計測する方法を開発した。これにより，特別な入力

* 川口大学工学部 宇部市常盤台 2-16-1

* Faculty of Engineering, Yamaguchi University, Ube

(Received May 14, 2003)

(Revised February 4, 2004) 装置を使用することなく，0.2s 程度の音圧変動デー夕を用い るたけで, 計測精度が $0.1 \sim 0.2 \%$ 位の高精度計測が実現でき た ${ }^{5)}$.さらに，上記線形ダイナミックシステムを構成する定 在波の最適モードの選択法を考えることにより，計測精度が 0.01 0.05\%のさらに高精度な管長計測法を開発した ${ }^{6)}$.

以上は，両端が閉の場合であったが，これに加えて，引き 続き，両端あるいは一端が開の管に対しても，管長と開口端 補正値を同時に高精度計測する手法を提案した ${ }^{7}$ ).

しかしながら，両端が開の管に対し，鋼管製造ヤードにお けるように大きな外乱音が絶えず管内に入る場合には，以前 のように鋼管をハンマーで吒いても，このときの衝撃音は外 乱音に埋もれることになる：そのため，管内定在波の位相が 頻繁に変わり，管内音圧変動を正弦波形によりモデル化する これまでの計測方式では，必ずしも良好な計測結果が得られ ないことがあることがわかった。つまり，適当にとったデー タウインドウに対し上記のように最適モードを選定しても， 管内音圧変動の位相が外乱により何回も変化するため, 計測 精度が劣化することがわかった。

そこで, 本論文では, 外乱音が大きい場合には, 以前のよ うに管に衝撃を与えることにより生じる定在波を用いるの ではなく，外部騒音によって管内に自然発生する定在波を積 極的に利用する方式を提案する。具体的には，与えられた観 測データの中から，最適なデータウインドウとそのとき使用 すべき最適モードを同時に選択し，これらにこれまでの管長 計測システムを適用することにより，高精度計測を実現する 方式を提案する，合わせて，実験により提案方式の有効性を 示す。なお, 外乱音が小さい場合は, 以前のように管にハン 
マーで衝撃を与え，これまでの計測システムをそのまま適用 す狆ば高精度な管長計測が可能であることはいうまでもない.

\section{2. 定在波を用いた管長計測システム}

Fig.1 に示す両端が開の長さ $L(\mathrm{~m})$ の直管において，短

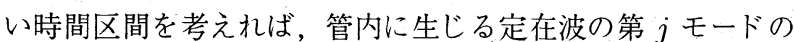
音圧変動 $x_{j}(t)$ は次式で表わされる.

$$
x_{j}(t)=\alpha_{j} \sin \left(\omega_{j} t+\phi_{j}\right) \quad(j=1,2,3, \cdots)
$$

ただし， $\omega_{j}$ は両端開の直管に対する第 $j$ モードの定在波の 角周波数 $\omega_{j}=j \times 2 \pi v /\{2(L+2 \delta)\} \quad(j=1,2, \cdots)$ を表わ す。ここに，vは管内音速である。また， $\delta$ は開口端補正值 であり，管の内径を $r$, 開口端補正係数を $c$ としたとき， $\delta$ $=c r / 2$ で与えられる ${ }^{8)}$. なお，開口端補正値 $\delta$ については, 管とフロアー（床）との距離がどのような值をとろうと，以 前提案の手法 ${ }^{7)}$ により高精度に計測することができるので， ここでは議論の簡潔さのため既知とする。

いま，管内音圧変動 $z(t)$ を 3 つの定在波モードの一次結合 で近似する。つまり，使用モードの集合として $\Omega=\left\{i_{1}, i_{2}, i_{3}\right\}$ を考え扎ば，管内音圧変動 $z(t)$ は次式で表わされる.

$$
z(t)=\sum_{j \in \Omega} x_{j}(t)
$$

このとき，上記の各定在波モードの音圧変動は $d^{2} x_{j}(t) / d t^{2}=-\omega_{j}^{2} x_{j}(t)(j \in \Omega)$ なる微分方程式を満な すので, 状態ベクトルを $\boldsymbol{x}=\left(x_{i 1}, \dot{x}_{i 1}, x_{i 2}, \dot{x}_{i 2}, x_{i 3}, \dot{x}_{i 3}\right)^{T}$ と定 義すれば，こ机ら音圧変動に対し，つぎのダイナミック方程 式が得ら扎る。

$$
\dot{\boldsymbol{x}}(t)=A \boldsymbol{x}(t)+\boldsymbol{w}(t)
$$

ここに，

$$
A=\left[\begin{array}{lll}
A_{1} & O & O \\
O & A_{2} & O \\
O & O & A_{3}
\end{array}\right], A_{j}=\left[\begin{array}{cc}
0 & 1 \\
-\omega_{i_{j}}^{2} & 0
\end{array}\right]
$$

ただし, $\boldsymbol{w}(t)=\left(0, w_{1}(t), 0, w_{2}(t), 0, w_{3}(t)\right)^{T}$ は遷移雑音て あり, $w_{j}(t)(j=1,2,3)$ はそれぞれ平均值ゼロ，分散 $\sigma^{2}$ の 互いに独立な白色ガウス雑音である。

いま，未使用の定在波すべてとセンサ本来の雑音を加えた ものを観測雑音 $v_{k}$ と見なせば，管内の音響センサにより与 えられる観測方程式は，上記の状態ベクトルを用いてつぎの ように表わされる。

$$
y_{k}=\boldsymbol{h} \boldsymbol{x}_{k}+v_{k}(k=0,1,2, \cdots)
$$

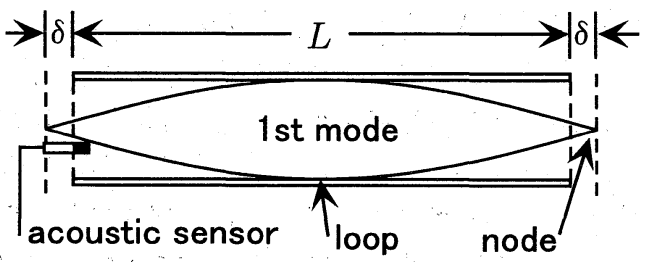

Fig. 1 Stationary waves in the pipe with two open ends
ただし， $\boldsymbol{h}=(1,0,1,0,1,0)$ であり， $\boldsymbol{x}_{k}$ は $k$ サンプリング 時刻における状態べクトル $\boldsymbol{x}(k \Delta T)$ の意である。

なお，文献 6) に示したように，多数のモードの定在波を 加え合わせたものは，白色ガウス雑音と仮定できるので，以 下では， $v_{k}$ を平均值がゼロ，分散が $V$ の白色ガウス雑音と して議論を進める.

\section{1 管長のリアルタイム計測法}

前節のようにして，管内音圧変動の線形ダイナミックシステ ムによるモデル化がなさ机たが，同システムにおいて，管長 $L$ および観測雑音分散 $V$ は共に未知である。したがって，これ ら 2 つの未知パラメータをまとめたベクトル $\boldsymbol{\theta}=(L, V)^{T}$ を定義し，実現した音圧変動に最も近接できる音圧変動を生 成できるパラメー夕 $\boldsymbol{\theta}$ を探索す狄ば，こ扎により管長 $L$ が 計測できることになる。つまり，つぎの尤度関数を最大化す ることにより $\boldsymbol{\theta}$ を求め机ば，管長計測がなされる ${ }^{5), 6) 。 ~}$

$$
\begin{aligned}
J(\boldsymbol{\theta}) & =p(\boldsymbol{y}, \boldsymbol{\theta}) \\
& =\prod_{k=1}^{K} p\left(y_{k} / \boldsymbol{\theta}, Y^{k-1}\right)
\end{aligned}
$$

ここに, $p\left(y_{k} / \boldsymbol{\theta}, Y^{k-1}\right)$ は観測情報 $Y^{k-1} \triangleq\left\{y_{j} ; 0 \leq j \leq\right.$ $k-1\}$ およびパラメータ $\theta$ のもとでの観測值 $y_{k}$ の条件付 き確率密度関数を表わす。 また, $\boldsymbol{y}=\left(y_{1}, y_{2}, \cdots, y_{K}\right)^{T}$ で ある。

したがって，計測に際しては，適切なデータウインドウお よびそのときの使用モードが決ま机ば， $\boldsymbol{\theta}$ を仮定した上記ダ イナミックシステムにカルマンフィルタ ${ }^{9)}$ 適用し，これに より求まる尤度関数 (6) 式の $\boldsymbol{\theta}$ についての最大化により管長 の計測がなされることになる5),6). なお，その際，カルマン フィルタを適用するため，(3) 式を離散形に置き換える必要 がある。

なお，上では $L$ と $V$ を未知パラメータとしたが，実際の 計測に際しては， $V$ は，適当な值を与え定数として差し支え

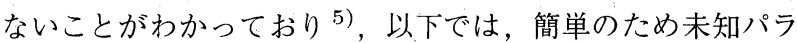
メータは $L$ だけとして話を進める。

次章では，管内定在波を邪魔する騒音のもとでの管内定在 波を用いた管長の高精度計測を実現するため，与えられた観 測デー夕に対し，最適ウインドウおよびそのときの最適モー ドを自動決定する方法について述べる。

\section{3. 最適データウインドウおよび最適モードの決定法}

先の研究においては，管長の高精度計測の観点から，ダイ バージェンス規範により線形ダイナミックシステムにおいて 採用する定在波最適モードの決定を考えた。つまり，フィッ シャーの情報行列 ${ }^{10)}$ （いまの場合はスカラー）

$$
\begin{aligned}
K(L)= & \int\left[\frac{\partial}{\partial L} \ell n p(\boldsymbol{y}, L)\right]\left[\frac{\partial}{\partial L} \ell n p(\boldsymbol{y}, L)\right]^{T} \\
& \times p(\boldsymbol{y}, L) d \boldsymbol{y}
\end{aligned}
$$

の最大化により最適モードを求めた ${ }^{7)}$.ここに, $p(\boldsymbol{y}, L)$ は 
観測值をまとめたベクトル $\boldsymbol{y}$ が従う確率密度関数を表わす. フイッシャーの情報行列は, 結局は, 対数尤度関数 $\ell n p(\boldsymbol{y}, L)$ を真值 $L$ の近傍で二次関数近似したときの二次の係数に相 当するため，これまでの情報行列最大化による最適モード選 択は, 結局は, 対数尤度関数 $\ell n p(\boldsymbol{y}, L)$ が急峻なモードの選 定と等価となる，ただ今回は，モードの選定だけでなく，ウ インドウの選定も新たに加わったことになる.

参考のため, 上記の等価性を以下に示す. まず, $y$ の従う 確率密度関数を

$$
\begin{aligned}
p(\boldsymbol{y}, L)= & \frac{1}{(2 \pi)^{K / 2}|V|^{1 / 2}} \\
& \times \exp \left[-\frac{1}{2}(\boldsymbol{y}-\boldsymbol{\beta}(L))^{T} V^{-1}(\boldsymbol{y}-\boldsymbol{\beta}(L))\right]
\end{aligned}
$$

とする。計測に使用するデータウインドウは短いため, こ の時間内では定在波はほとんど減衰しないと思われるので,

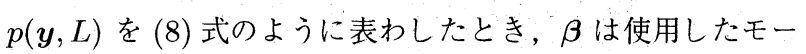
ド周波数に対応する正弦波の和をサンプリングしたもの(べ クトル）となる.もちろん，Lの関数となることは明らかで ある.このとき, $\ell n p(\boldsymbol{y}, L)$ を $L$ の近傍で 2 次のオーダー までテイラー展開すれば,

$$
\begin{aligned}
\ln p(\boldsymbol{y}, L)= & -\frac{1}{2}\left(\frac{\partial \boldsymbol{\beta}}{\partial L}\right)^{T} V^{-1}\left(\frac{\partial \boldsymbol{\beta}}{\partial L}\right)(\Delta L)^{2} \\
& +(\boldsymbol{y}-\boldsymbol{\beta}(L))^{T} V^{-1}\left(\frac{\partial \boldsymbol{\beta}}{\partial L}\right) \Delta L+\text { const } .
\end{aligned}
$$

一方，(7) 式の情報行列は次式で求まる.

$$
\begin{aligned}
K(L)= & \int\left(\frac{\partial \boldsymbol{\beta}}{\partial L}\right)^{T} V^{-1}(\boldsymbol{y}-\boldsymbol{\beta}(L))(\boldsymbol{y}-\boldsymbol{\beta}(L))^{T} \\
& \times V^{-1}\left(\frac{\partial \boldsymbol{\beta}}{\partial L}\right) p(\boldsymbol{y}, L) d \boldsymbol{y} \\
= & \left(\frac{\partial \boldsymbol{\beta}}{\partial L}\right)^{T} V^{-1}\left(\frac{\partial \boldsymbol{\beta}}{\partial L}\right)
\end{aligned}
$$

よって, (9), (10) 式より, 情報行列と対数尤度関数の急峻度 が等価となることがわかる.

これまでの計測方式では, 単に, ある衝撃により管内に定 在波を発生させたり, あるいは管内に自動発生した定在波を 利用し，これら定在波を管内音響センサより抽出し管長を計 測する方式であった。それゆえ, 発生した定在波は通常ある 時間だけ継続し消滅する。したがって，この時間内では，減 衰が余りない範囲では，どのような長さのデータウインドウ を採用してもよかったが, 今回は衝撃による定在波あるいは 自動発生している定在波は, 管外からの入射騒音に打ち消さ れたり, あるいは外乱音のため管内定在波の位相が突変し, 管内定在波を正弦波でモデル化し管長計測を行なっていた先 の提案方式では計測誤差が増大する.

そこで, ここでは, 第 2 章で述べた尤度関数を用いて最適 ウインドウおよび最適モードを同時決定することを考える. なお本論文では, 先の等価性の事実から情報行列の代りに対 数尤度関数の急峻度を活用し, 尤度関数のピーク形状が鋭く なるデータウインドウおよびモードを選択することになる.
そして, 求まったこ机ら最適データウインドウ, 最適モード に対し，これまで著者らが開発して来た計測方式を採用する ことにより管長を計測する。

この方式では, フィッジャーの情報行列の最大化を図る方 式に比べて別の利点もある.つまり, フィッシャーの情報行 列は本来局所的なものであるが, 尤度関数の形状をみて最適 なデータウインドウおよびモードを選択する今回の提案方式 では, 計測に使えないデータの判定も可能となる.

つまり，物理的には，外乱音がない場合は定在波は厳密に 基本モードの周波数の整数倍の周波数を持つため, 尤度関数 は常に単一のピークを持つ.ところが，外乱音により頻繁に 大きな位相の突変が生じる場合は, ( ウインドウ内で平均的に 見た）等価的周波数がシフトするため，おのおのの周波数が 異なった管長に対する定在波モードとしての働きをなし，尤 度関数（あるいは対数尤度関数）が複数のピークを持つこと になる，なお，位相の突变が多数生じ，たまたま周波数シフ トが打ち消し合い, 尤度関数のピークがひとつになる場合も 考えられるが，このような場合には尤度関数のピーク形状は 必然的に緩やかとなる。これは，管長パラメー夕 $L$ を多少 変化させても, 位相が頻繁に変化しているため, 音圧モデル によりデータウインドウ内の音圧変動をある程度表わすこと ができるからである.

以上のことから, 対数尤度関数がひとつのピークを持ち, かつこのピーク形状が最も急峻となるデータウインドウおよ び定在波モードを最適なものとして選ぶことが合理的である ことがわかる.

上記手法により求めた最適データウインドウと最適モード を用いて第 2 章の計測法を適用することにより，外乱音が開 口端より入る開管の場合にも，管内定在波モードを効率的に 抽出した管長高精度計測が実現されることになる。なお，本 計測システムにおいては外乱音にようて管内に生じる定在波 を利用するため，外乱音のレベルが増大した場合でも，信号 (使用モードの定在波) および観測雑音（未使用モードの定 在波）が共に大きくなるだけで相対的な大きさは変わらない. したがって, 外乱音の大きさが変わっで, 管長高精度計測 が可能である.ただ緒言でも述べたように，外乱音が小さい 場合は，この方法よりハンマーで衝撃を与える以前の方法の 方が有効である。

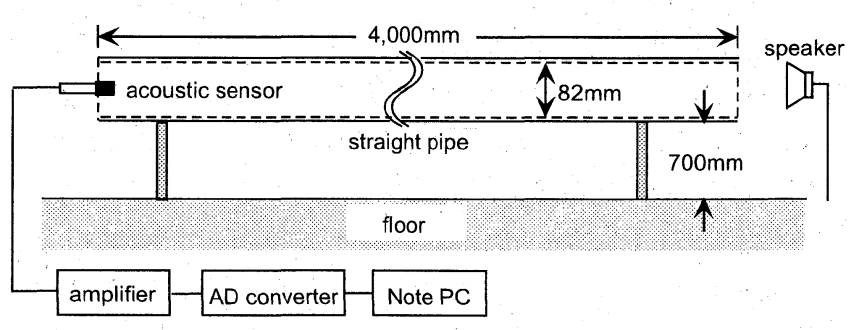

Fig. 2 Outline of the experiment 


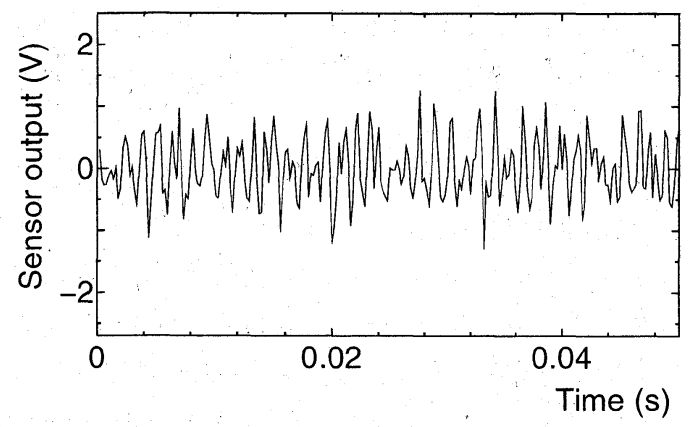

Fig. 3 Output of the sensor inside the pipe

\section{4. 実験結果および検討}

管長計測実験を Fig.2 に示す長さ $4,000 \mathrm{~mm}$, 内径 $82 \mathrm{~mm}$ の両端開の直管に対して行なった。なお，本実験においては， 緒言で述べたように管に衝撃を与えるのではなく, 鉄鋼製造 ヤードのようにかなり大きな騒音がある環境下を想定し，管 口に向けて約 $100 \mathrm{~dB}$ の外乱音を入力した。この際，外乱音 は図のようにセンサ位置とは異なる管端の方にセットしたス ピーカより入射した。 なお，外乱音としては，選択周波数を 特定の局の周波数に同調させない状態のラジオ出力とした. また，管を床から 700mm 離しておいたのは，開口端補正を 行なう際，理想的な開口端に対する補正值 $c=0.613$ が使用 できるようにしたためである7)。さらに，管内に設置した温 度センサにより実験時の管内温度を測定したところ, $21.5^{\circ} \mathrm{C}$ であった。

上記の実験条件のもとで，管内音圧変動データをサンプリ ング周期 $\Delta T=0.2 \mathrm{~ms}$ で $10 \mathrm{~s}$ 間パソコンに収録した。このと きの管内音響センサの出力波形および (参考のため) スピー 力側の管外に置いた音響センサの出力波形をそ机ぞれ Fig.3， 4 に示す，なお，図には，定在波の影響が見えやすいよう， $0.05 \mathrm{~s}$ 間の音圧変動波形を示している. 実際, Fig.4の波形と 異なり, Fig.3の波形には強い周期性がみられる。参考のた め, Fig.5，6に：これらの出力のスペクトルをそれぞれ示 す. Fig.5, 6 より，管内音圧変動は管外音圧変動（この場合 はスピーカからの直接音）と異なり，スペクトル図において も周期的な位置に急峻なピークがあることがわかる。つまり， 管内音圧変動に複数の定在波が含ま机ていることがわかる． なお，このときの理論的な基本モードの周波数は $42.5 \mathrm{~Hz}$ で あり, Fig.5の急峻なピークはこの基本モード周波数の整数 倍の位置にあることがわかる。

参考のため, Fig.7 に静寂な環境下での管に軽くハンマー で衝撃を与えたときの管内音圧変動のスペクトルを示すが, Fig.5, 7 より，外乱音がある場合は，そうでない場合に比べ て, 各モード周波数の近傍でスペクトルのピーク形状が比較 的緩やかとなっていることがわかる．さらに，ピークの数が 減ったり，あるいは余分なピークが現れたりしていることも わかる。

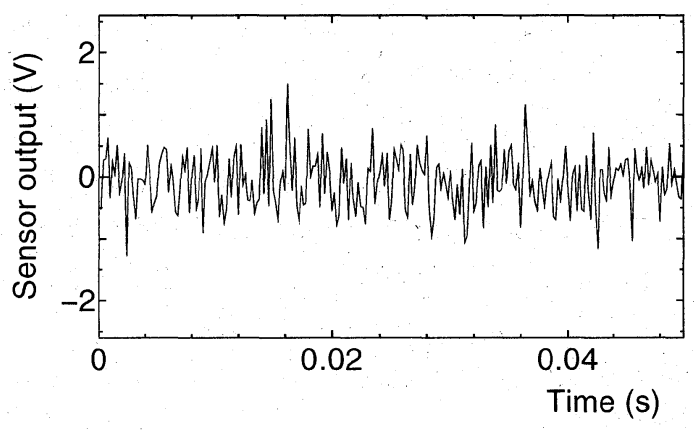

Fig. 4 Output of the sensor outside the pipe (near the speaker)

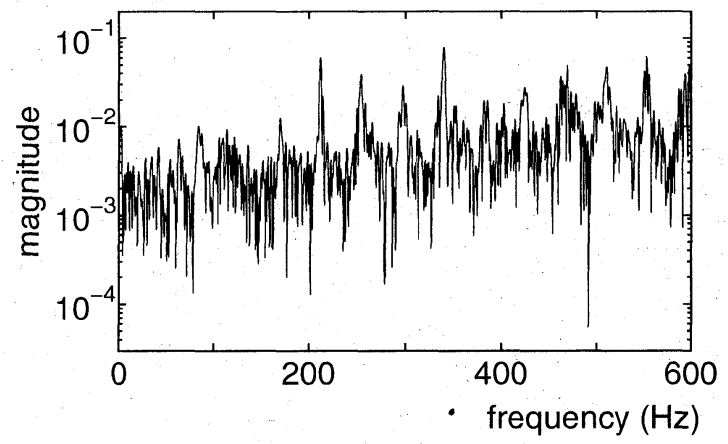

Fig. 5 Spectrum of the output of the sensor inside the pipe

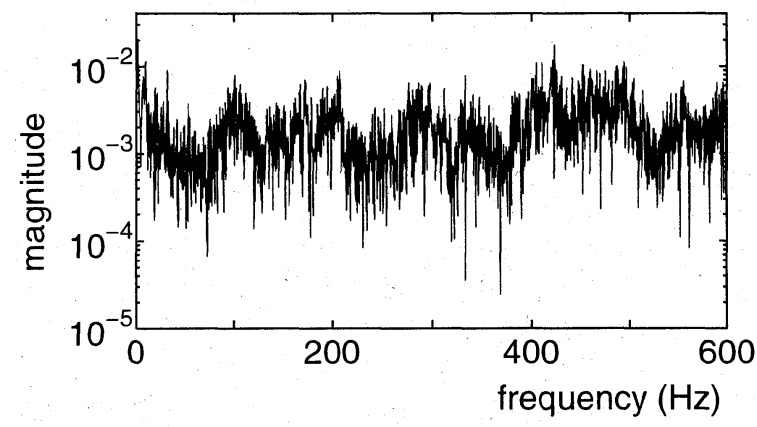

Fig, 6 Spectrum of the output of the sensor outside the pipe

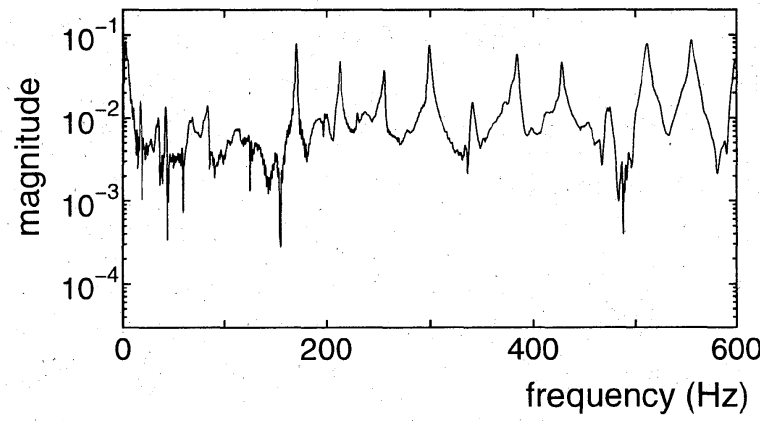

Fig. 7 Spectrum of the output of the sensor inside the pipe under no external noise

つぎに，管内音響センサにより得られた $10 \mathrm{~s}$ 間の観測デー タに対し，データウインドウ長を $2 \mathrm{~s} に$ 固定し，データウイン 


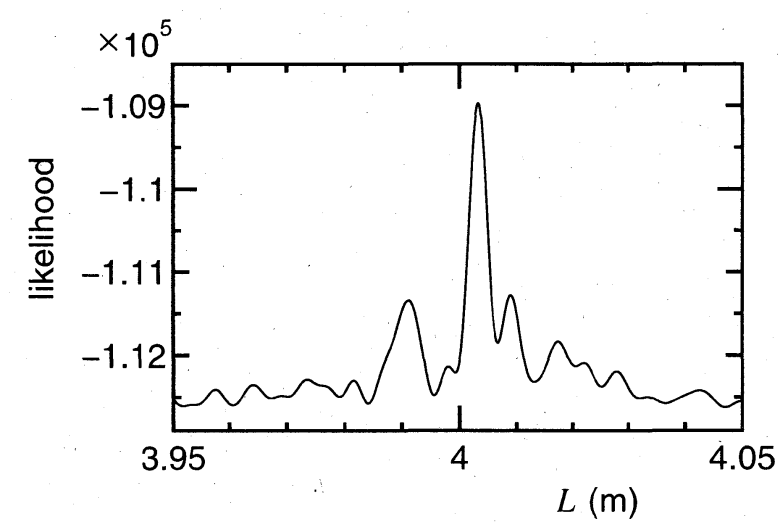

Fig. 8 A likelihood function for the optimal data window with the optiaml modes

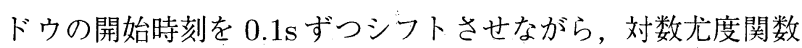
のピークの先鋭度が最大となるものを捜した．ただし，対数 尤度関数の計算に際しては, 第 13 モードを上限としたモー ドの中から $3 つ の$ 最適モードを選択することにした。なお，

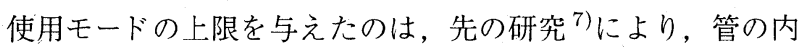
径の 8 倍より短い波長の定在波を使用すると，管内平面波の 仮定がこわれ，管長計測に誤差が生じることを考慮したから である。

この結果, 先鋭度が最大となったのは, データウイン ドウの開始時刻が $6.9 \mathrm{~s}$ (つまり,データウインドウが $\left.D^{*}=[6.9,8.9]\right)$ のときであり, かつこのときの最適モー ドは $\Omega^{*}=\{5,8,13\}$ となった。この最適なデータウインドウ $D^{*}$ および最適な定在波モード $\Omega^{*}$ に対し第 2 章の計測シス テムを適用すると，管長の計測值は $4.003 \mathrm{~m}$ となった。参考 のため, このときの対数尤度関数の变化を， $3.95 \leq L \leq 4.05$ (m) の範囲で描いたものが Fig.8である.また, 同様な実験 を 10 回行なったときの計測值の平均值および平均值周りの 標準偏差はTable 1 のようになった。なお表には, 参考の ため, 採取した $10 \mathrm{~s}$ 間の音圧デー夕の最初の $2 \mathrm{~s}$ 間をデー夕 ウインドウとして用いたときの, 以前提案の方法による計測 結果もあわせて示す。

Table 1 Measurement results

\begin{tabular}{|l|r|r|}
\hline & mean $(\mathrm{mm})$ & SD $(\mathrm{mm})$ \\
\hline true & 4,000 & \\
\hline \hline proposed method & 4,002 & 3.7 \\
\hline pre-proposed method & 4,004 & 14.6 \\
\hline \multicolumn{3}{|c|}{ SD : standard deviation }
\end{tabular}

表より，単にデータウインドウを適当なものに固定して最 適モードモデルを使用するだけの方式に比べ，本論における 提案方式のほうが格段に高精度な計測が行なえることがわか る. 参考のため, Fig.9に,データウインドウを $[0,2.0]$ と したものに以前提案の方式を適用したときの対数尤度関数の 一例を示すが, 適当にデータウインドウを選んだ場合, 最適 モードを使用しても, 対数尤度関数のピークの尖鋭さは, 提

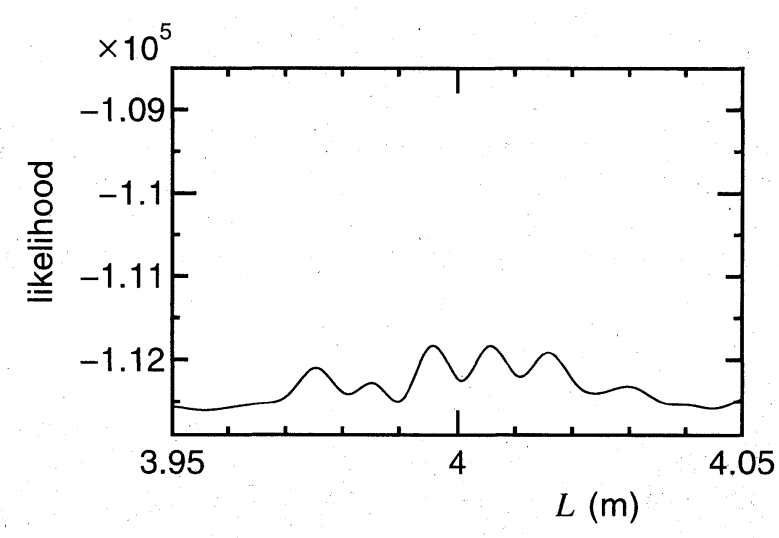

Fig. 9 A likelihood function for a data window $[0,2.0]$ with the optimal modes

案手法の場合（たとえば，Fig.8）に比較し大幅に減じること

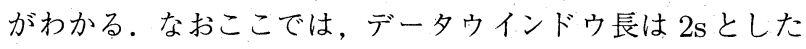
が，具体的な選定に当っては，適用対象ごとにあらかじめ実 験などを行ない，最適なものを用いるようにすればよい，最 後に，本実験では長さ $4 \mathrm{~m}$ の管に対して計測実験を行なった が，本計測システムにおいては，計測誤差は管内に発生する 定在波モードの波長によって決まるため, 内径が同じ管であ れば，基本的には計測精度は管の長さに影響されない7).

\section{5. 結言}

こ北まで著者らは，両端が閉じた管あるいは静寂な環境下 での（一端あるいは両端が開の）開管に対し，管内に発生し た定在波を用いたシステム工学的発想による管長高精度自動 計測法を提案して来たが, 本論文では, 尤度関数のピークが 最も先鋭となるデータウインドウおよびそのとき定在波の最 適モードを使用することにより，外乱音が開口端より管内に 入り管内定在波に影響を与える場合でも，高精度な管長計測 が行なえる計測システムを提案した。そして，実験により， 本提案方式の有効性を確認した.

最後に, 本研究の遂行に際し, ご協力を戴いた本学電気電 子工学科岡本昌幸助手に謝意を表す次第である.

\section{参 考文. 献}

1) T. Manabe, S. Tomita and T. Yabuta: Acoustic Inspection System for Underground Telecommunication Conduit, Proc. of IMTC'94 (1994)

2）佐藤，田伊，伊藤：音響を利用したパイプ長長さ計測, 第 36 回自動制御連合講演会予稿集, 11/12 (1993)

3）小川, 渡辺：音響法によるパイプラインモニタリング, 計測自 動制御学会論文集, 29-3, 295/301 (1993)

4）一宮，坂本：音響信号を利用した管の長さ測定（管内空気柱の 共振周波数測定)，日本機械学会論文集，57-539, 2217/2222 (1991)

5）田中, 岡本: 管内音圧変動を利用した管長オンライン計測, 計 測自動制御学会論文集, 34-2, 78/86 (1998)

6) S. Tanaka and M. Okamoto: Dynamic Model Based Pipe Length Measurement Using Stationary Wave, Measurement, 28, 249/259 (2000)

7）田中，岡本：定在波を用いた両端開の直管に対する管長高精 
度計測，計測自動制御学会論文集， 38-10, 821/828 (2002)

8) 小橋 豊：基礎物理学選書 音と音波, 裳華房 (1969)

9）有本 卓：カルマン・フィルター, 産業図書 (1977)

10) S. Kullback: Information Theory and Statistics, John Wiley and Sons (1959)

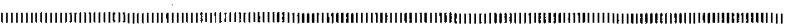

[著者 紹 介]

田 中 正 吾(正会員)

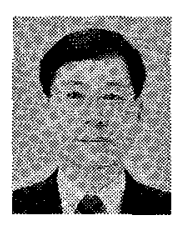

1976 年, 九州大学大学院電気工学専攻博士課 程修了. 同年同大学助手を経て, 80 年川吅大学工 学部電子工学科助教授. 91 年同大学電気電子工学 科教授，現在に至る。インテリジェント計測，異 常診断などの理論㧍よび応用研究に従事 (工学博 士). 電気学会,システム制御情報学会などの会 員，中国文化賞 (2003)，文部科学大臣賞 (2004) などを受賞, 本会フェロー(2003).

中 山 正 行 (学生会員)

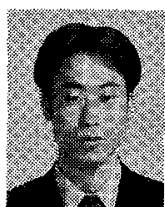

2004 年11口大学大学院理工学研究科博上前期 課程電気電子工学専攻修了. 現在, 日本製紙 (株) 勤務. 在学中は音響センサを用いた管長自動計測 システムの開発に関する研究に従事.

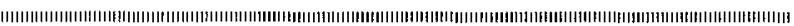

